Supporting information of

\title{
Monomeric Three-coordinate N-Heterocyclic Carbene Nickel(I) Complexes: Synthesis, Structures and Catalytic Applications in Cross-Coupling Reactions
}

Kouki Matsubara, ${ }^{* \dagger}$ Yukino Fukahori, ${ }^{\dagger,}$ Takahiro Inatomi, ${ }^{\dagger}$ Saeko Tazaki, ${ }^{\dagger}$ Yuji Yamada, ${ }^{\dagger}$ Yuji Koga, ${ }^{\dagger}$ Shinji Kanegawa, ${ }^{\S}$ and Toshikazu Nakamura ${ }^{\star}$

† Department of Chemistry, Faculty of Science, Fukuoka University. 8-19-1 Nanakuma, Fukuoka 814-0180, Japan.

千 Institute for Molecular Science, Myodaiji, Okazaki, Aichi 444-8585, Japan.

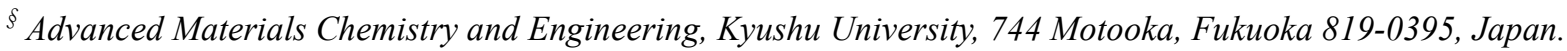

\section{Contents}

S-1. Preparation of Monomeric Nickel NHC Complexes [NiCl(L)(IPr)] (2b-d) $\left(\mathrm{L}=\mathrm{P}(\mathrm{OPh})_{3} ; 2 \mathrm{~b}\right.$, Pyridine ; $\left.2 \mathrm{c}, \mathrm{dppb} ; 2 \mathrm{~d}\right)$

S-2. Solution Behavior in the Reaction Media with Bidentate Phosphines

S-3. Preparation of the Monomeric IMes Complexes (3a,3b)

S-4. Buchwald-Hartwig Amination to Yield Triarylamines

S-5. SQUID Measurement of the Ni(I) Complexes

S-6. Suzuki-Miyaura Cross-Coupling Reaction of Aryl Bromide with Phenylboronic Acid

References 


\section{S-1. Preparation of Monomeric Nickel NHC Complexes [NiCl(L)(IPr)] (2b-d)}

[NiCl(P(OPh) $)(\mathbf{I P r})](\mathbf{2 b}):$ The $\mathrm{Ni}(\mathrm{I})$ complex was prepared according to the similar method in the literature. ${ }^{1}$ In a glove box, $[\mathrm{Ni}(\mathrm{IPr})]_{2}(\mu-\mathrm{Cl})_{2}(\mathbf{1})(0.03 \mathrm{mmol}, 30 \mathrm{mg}), \mathrm{P}(\mathrm{OPh})_{3}(0.06 \mathrm{mmol}, 15 \mu \mathrm{L})$, and THF $(0.5 \mathrm{~mL})$ were added to a $5 \mathrm{~mL}$ screw-capped tube. After the compounds were dissolved, $\mathrm{n}$-hexane $(1.5 \mathrm{~mL})$ was slowly added to the solution and cooled to $-30^{\circ} \mathrm{C}$. Colorless crystals of $\mathbf{2} \mathbf{b}$ were obtained, after removal of the liquid and washing with small amount of hexane ( $85 \mathrm{mg}, 88 \%$ yield). ${ }^{1} \mathrm{H}$ NMR $\left(\mathrm{C}_{6} \mathrm{D}_{6}\right): \delta 1.62$ (bs), 4.13 (bs), 6.94 (bs), 7.68 (bs), 8.09 8.31 (bs), 10.44 (bs). Elemental analysis, calcd. (\%) for $\mathrm{C}_{45} \mathrm{H}_{51} \mathrm{~N}_{2} \mathrm{O}_{3}$ PClNi: C, 68.16; H, 6.48; N, 3.53. Found: C, 68.63; H, 6.59; N, 3.57.

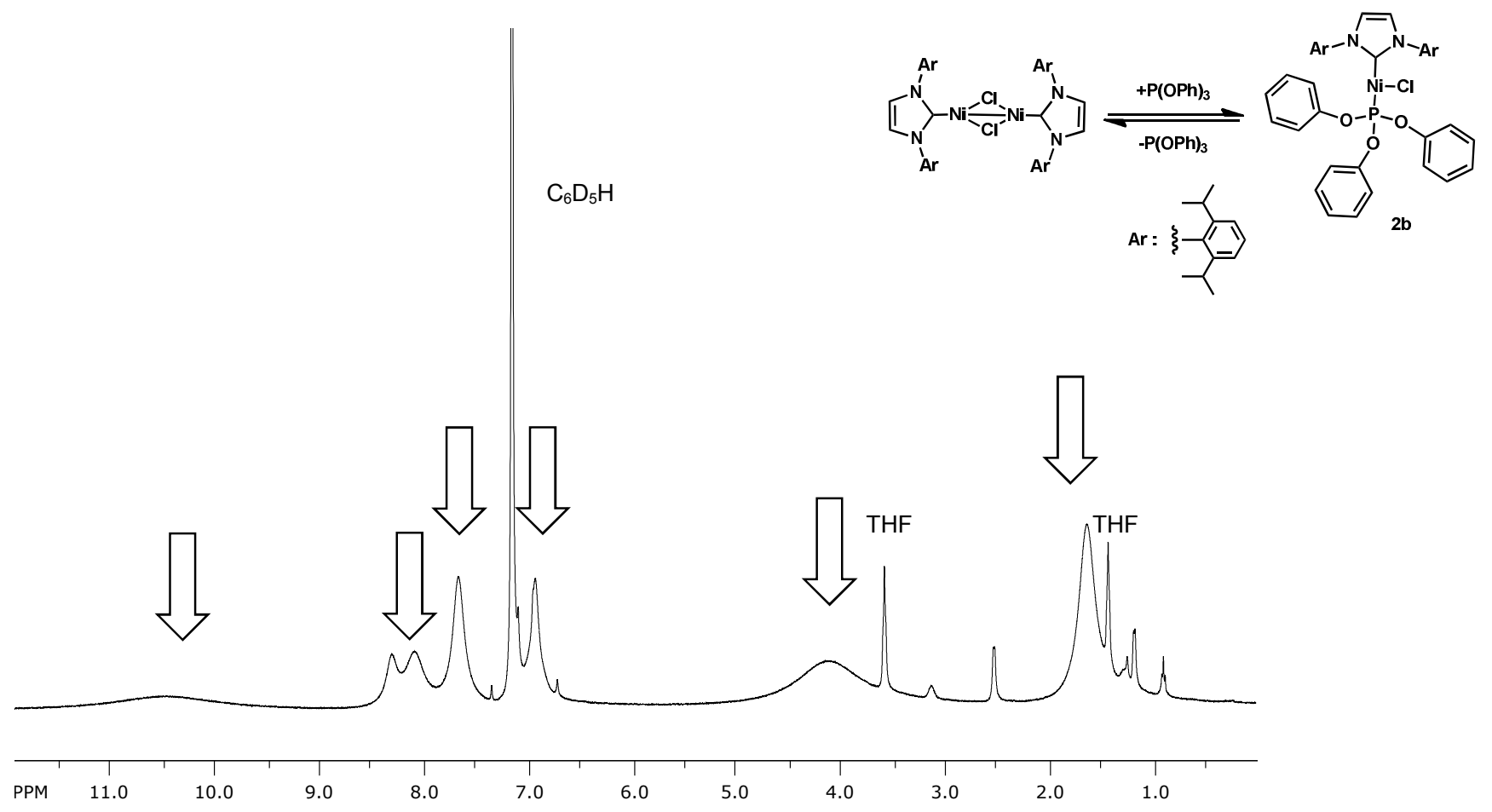

Figure S1. ${ }^{1} \mathrm{H}$ NMR spectra for $\mathbf{2 b}\left(400 \mathrm{MHz}\right.$, benzene- $\left.d_{6}\right)$ 
[NiCl(Py)(IPr)] (2c): In a glove box, $[\mathrm{Ni}(\mathrm{IPr})]_{2}(\mu-\mathrm{Cl})_{2}(\mathbf{1})(0.03 \mathrm{mmol}, 30 \mathrm{mg})$, pyridine $(0.12 \mathrm{mmol}$, $9.6 \mu \mathrm{L})$, and THF $(0.5 \mathrm{~mL})$ were added to a $5 \mathrm{~mL}$ screw-capped tube. After the compounds were dissolved, n-hexane $(1.5 \mathrm{~mL})$ was slowly added to the solution and cooled to $-30^{\circ} \mathrm{C}$. Vermillion crystals of $\mathbf{2 c}$ were obtained, after removal of the liquid and washing with small amount of hexane (24 $\mathrm{mg}, 69 \%$ yield). ${ }^{1} \mathrm{H}$ NMR $\left(\mathrm{C}_{6} \mathrm{D}_{6}\right): \delta 1.18$ (bs), 1.75 (bs), 2.48 (bs), 3.08 (bs) , 6.37 (bs) , 6.95 (bs) , 10.7 (bs). Elemental analysis, calcd. (\%) for $\mathrm{C}_{32} \mathrm{H}_{41} \mathrm{~N}_{3} \mathrm{ClNi}$ C, 68.41; H, 7.36; N, 7.48. Found: C, 68.33; H, 7.32; N, 7.38 .

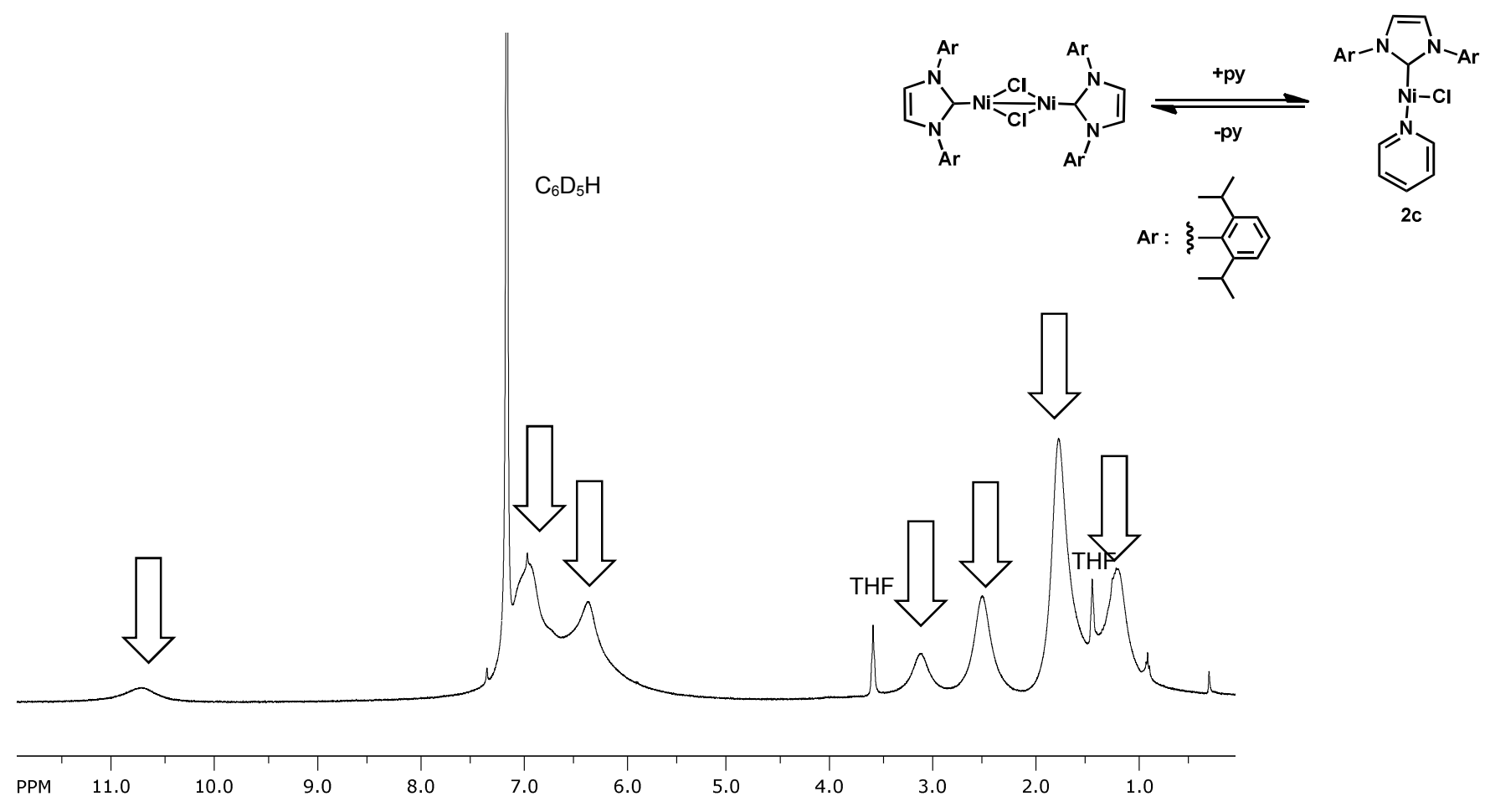

Figure S2. ${ }^{1} \mathrm{H}$ NMR spectra for $2 \mathbf{c}\left(400 \mathrm{MHz}\right.$, benzene- $\left.d_{6}\right)$ 
$[\mathbf{N i C l}(\mathrm{IPr})]_{2}(\mathbf{d p p b})(\mathbf{2 d}):$ In a glove box, $[\mathrm{Ni}(\mathrm{IPr})]_{2}(\mu-\mathrm{Cl})_{2}(\mathbf{1})(0.05 \mathrm{mmol}, 48 \mathrm{mg})$, dppb $(0.05 \mathrm{mmol}$, $21 \mathrm{mg}$ ), and THF $(0.5 \mathrm{~mL})$ were added to a $5 \mathrm{~mL}$ screw-capped tube. After the compounds were dissolved, $\mathrm{n}$-hexane $(1.5 \mathrm{~mL})$ was slowly added to the solution and cooled to $-30^{\circ} \mathrm{C}$. Yellow crystals of 2d were obtained, after removal of the liquid and washing with small amount of hexane (63 $\mathrm{mg}, 91 \%$ yield). ${ }^{1} \mathrm{H}$ NMR $\left(\mathrm{C}_{6} \mathrm{D}_{6}\right): \delta 1.75$ (bs), 4.55 (bs), 8.52 (bs), 10.78 (bs). Elemental analysis, calcd. (\%) for $\mathrm{C}_{45} \mathrm{H}_{51} \mathrm{~N}_{2} \mathrm{O}_{3} \mathrm{PClNi}$ : C, 70.76; H, 7.24; N, 4.03. Found: C, 70.06; H, 7.33; N, 3.77.
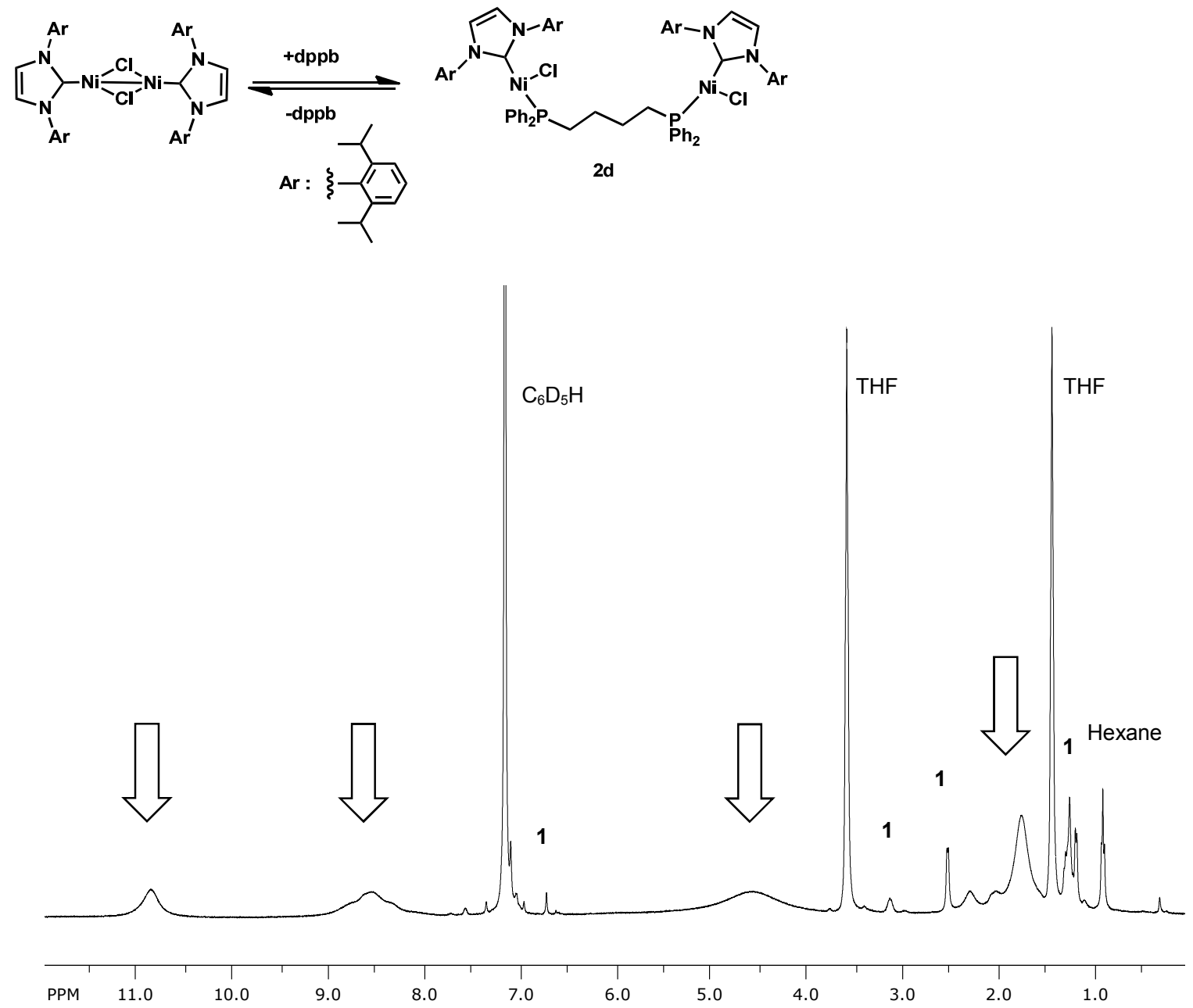

Figure S3. ${ }^{1} \mathrm{H}$ NMR spectra for $\mathbf{2 d}\left(400 \mathrm{MHz}\right.$, benzene- $\left.d_{6}\right)$ 


\section{S-2. Solution Behavior in the Reaction Media with Bidentate Phosphines}

\section{S-2-1. Reaction of 1 with dppe and dppp}

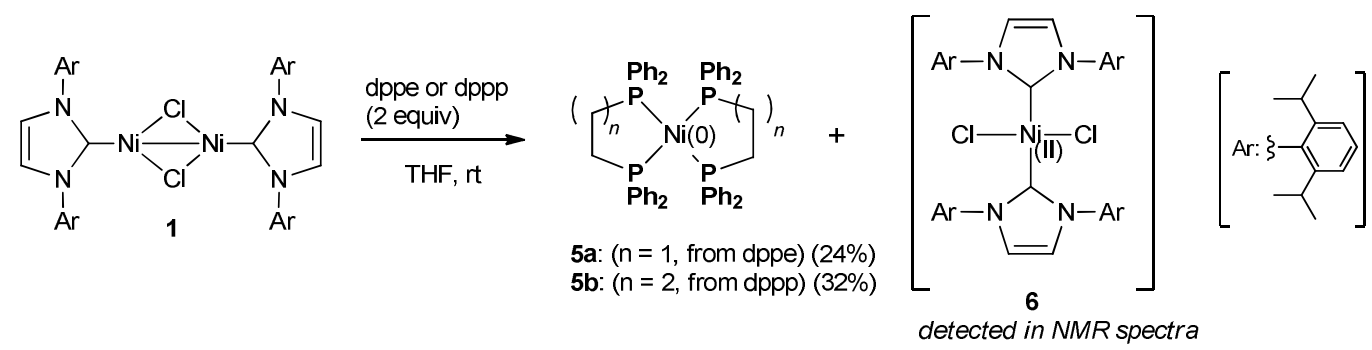

\section{Scheme S1. Reactions of 1 with diphosphines, DPPE and DPPP}

The reaction of complex 1 with 2 equiv. of dppe (1,2-bis(diphenylphosphino)ethane) or dppp (1,2-bis(diphenylphosphino)propane) in THF at room temperature immediately occurred to give a mixture of zerovalent $\mathrm{Ni}(0)$ complex, $\mathrm{Ni}(\mathrm{dppe})_{2}(\mathbf{5 a})$ or $\mathrm{Ni}(\mathrm{dppp})_{2}(\mathbf{5 b})$, and divalent nickel chloride, $\mathrm{NiCl}_{2}(\operatorname{IPr})_{2}$, which were clearly detected in NMR spectra (Figures S4, S8). A

lthough the formation of the nickel(II) chloride was confirmed by the ${ }^{1} \mathrm{H}$ NMR spectra of the mixtures, the nickel(0) phosphine complexes were successfully isolated as yellow and red-orange crystals and determined by NMR spectroscopy (Figures S5, S6, S7, S9, S10, S11). The yields of 5a and 5b were 24 and $32 \%$, respectively, upon crystallization.

\section{S-2-2. Reaction of 1 with dppe}

In a glove box, $[\mathrm{Ni}(\mathrm{IPr})]_{2}(\mu-\mathrm{Cl})_{2}(\mathbf{1})(0.03 \mathrm{mmol}, 30 \mathrm{mg})$, dppe $(0.06 \mathrm{mmol}, 24 \mathrm{mg})$, and THF $(0.5 \mathrm{~mL})$ were added to a $5 \mathrm{~mL}$ screw-capped tube. After the compounds were dissolved, $\mathrm{n}$-hexane $(1.5 \mathrm{~mL})$ was slowly added to the solution and cooled to $-30^{\circ} \mathrm{C}$. Yellow crystals of $\mathbf{5 a}$ were obtained, after removal of the liquid and washing with small amount of hexane (12 mg, 24\% yield). ${ }^{1} \mathrm{H}$ NMR (400 MHz, $\left.\mathrm{C}_{6} \mathrm{D}_{6}\right): \delta$ $=2.10(\mathrm{t}, 4 \mathrm{H}), 6.93(\mathrm{~m}, 12 \mathrm{H}), 7.47(\mathrm{br}, 8 \mathrm{H}) .{ }^{13} \mathrm{C} \mathrm{NMR}\left(100 \mathrm{MHz}, \mathrm{C}_{6} \mathrm{D}_{6}\right): \delta=30.05,31.32,32.63,131.85$, 133.43, 14.56. ${ }^{31} \mathrm{P}$ NMR $\left(162 \mathrm{MHz}, \mathrm{C}_{6} \mathrm{D}_{6}\right): \delta=44.08$ (s). 


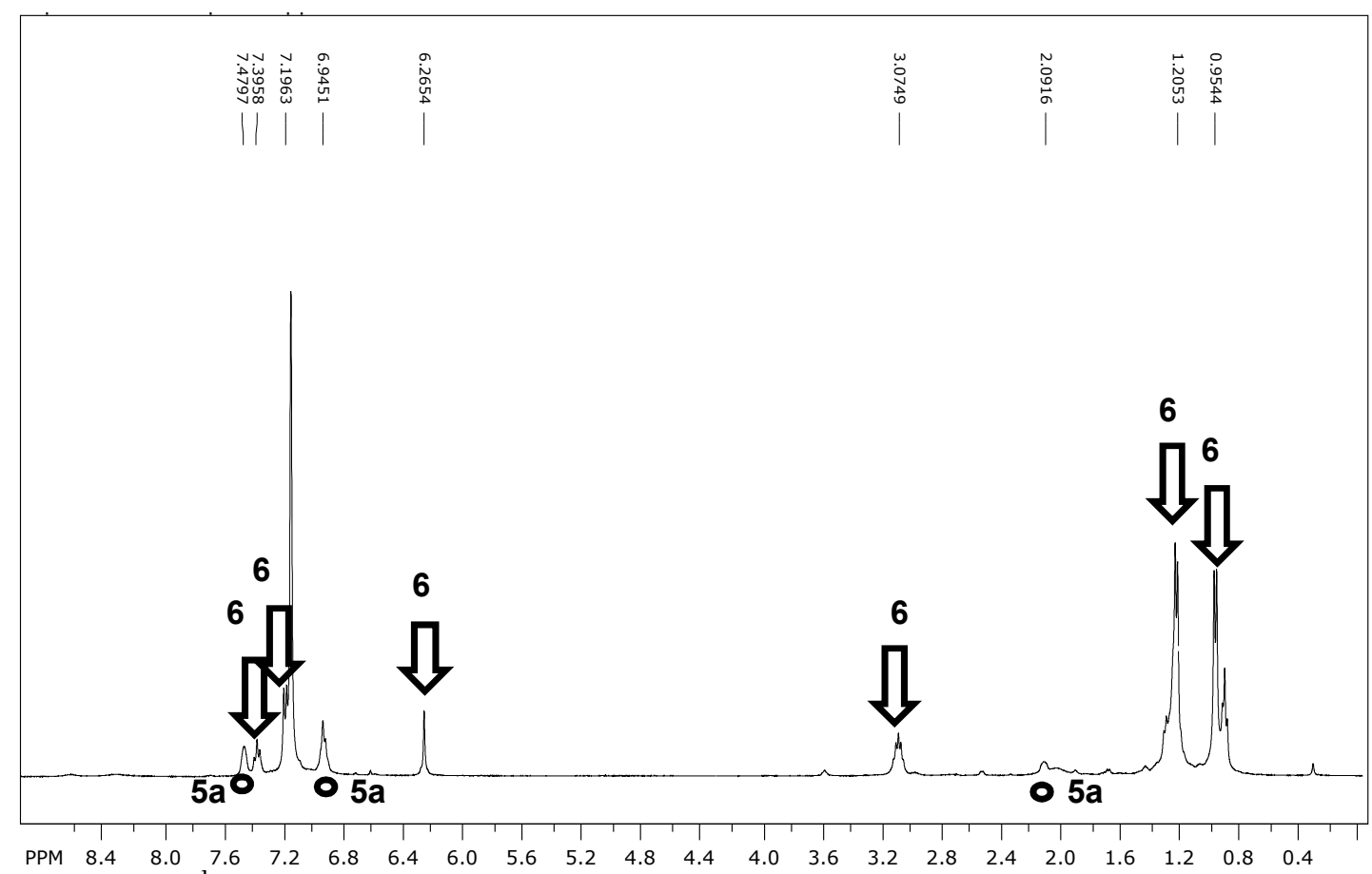

Figure S4. ${ }^{1} \mathrm{H}$ NMR spectra $\left(400 \mathrm{MHz}\right.$, benzene- $\left.\mathrm{d}_{6}\right)$ of the reaction mixture containing $5 \mathbf{a}(\circ)$ and $6(\downarrow)$

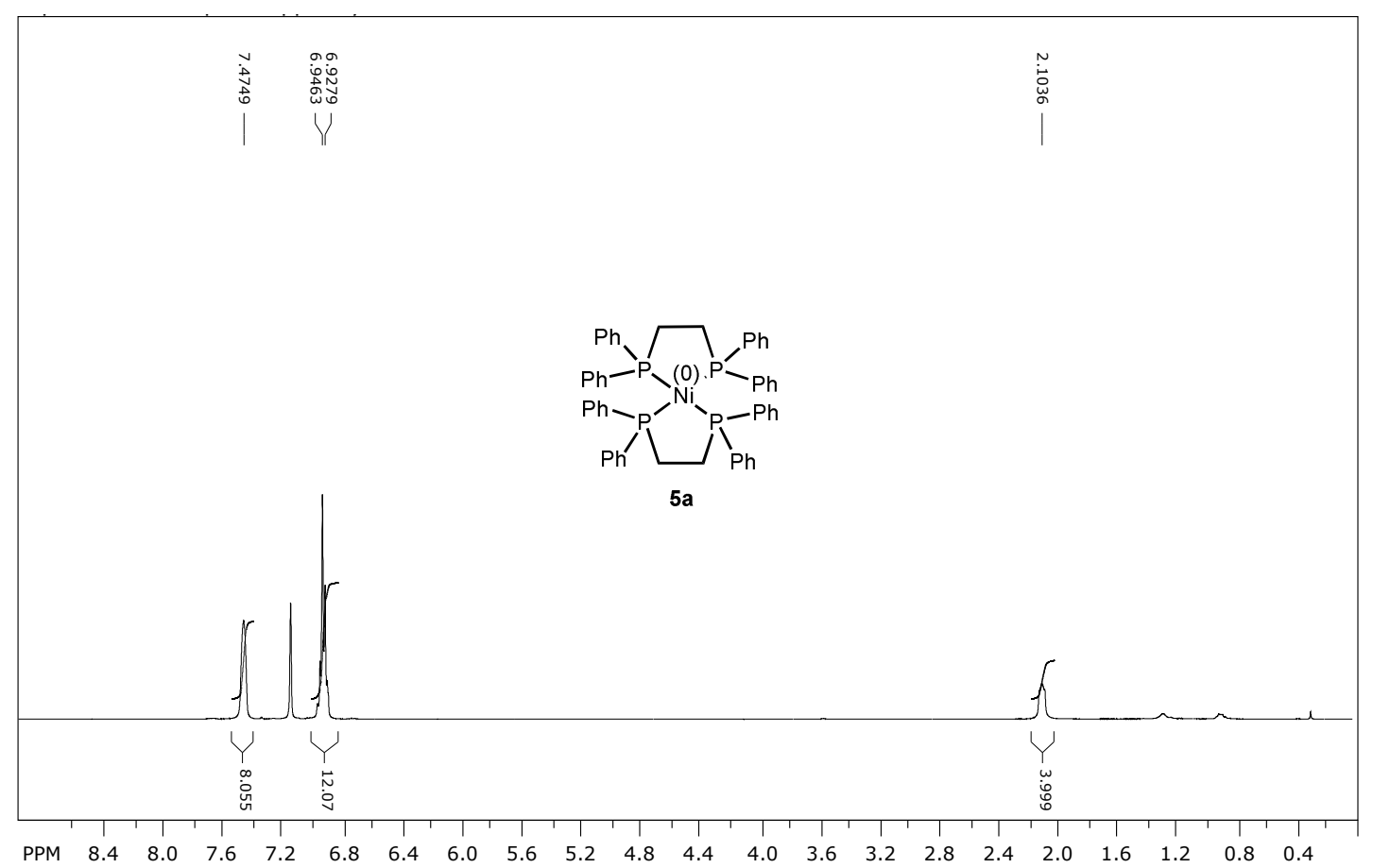

Figure S5. ${ }^{1} \mathrm{H}$ NMR spectrum $\left(400 \mathrm{MHz}\right.$, benzene- $\left.\mathrm{d}_{6}\right)$ of $\mathrm{Ni}(\mathrm{dppe})_{2}(\mathbf{5 a})$ after isolation 


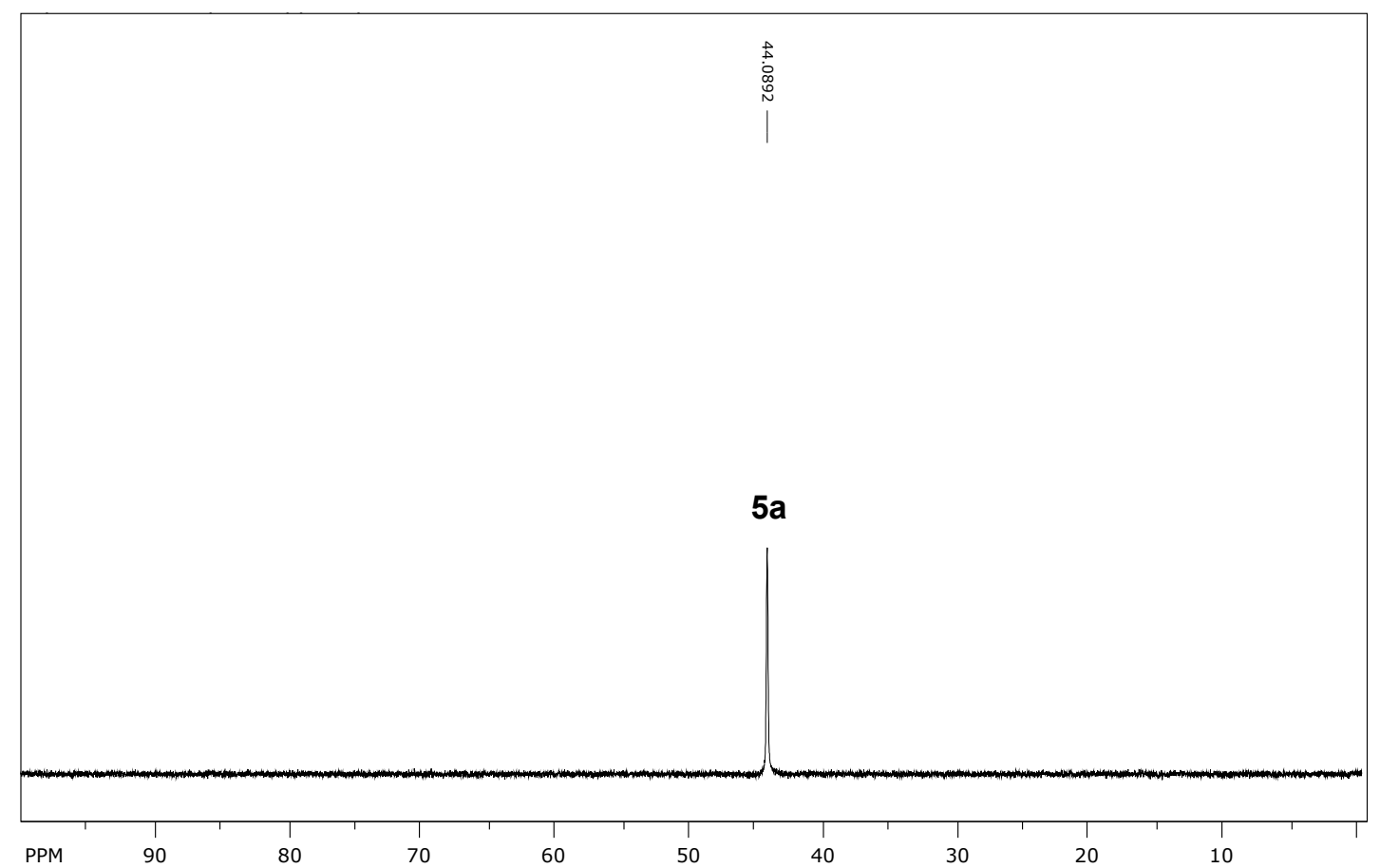

Figure S6. ${ }^{31} \mathrm{P}$ NMR spectrum $\left(162 \mathrm{MHz}\right.$, benzene- $\left.\mathrm{d}_{6}\right)$ of $\mathrm{Ni}(\mathrm{dppe})_{2}(\mathbf{5 a})$ after isolation

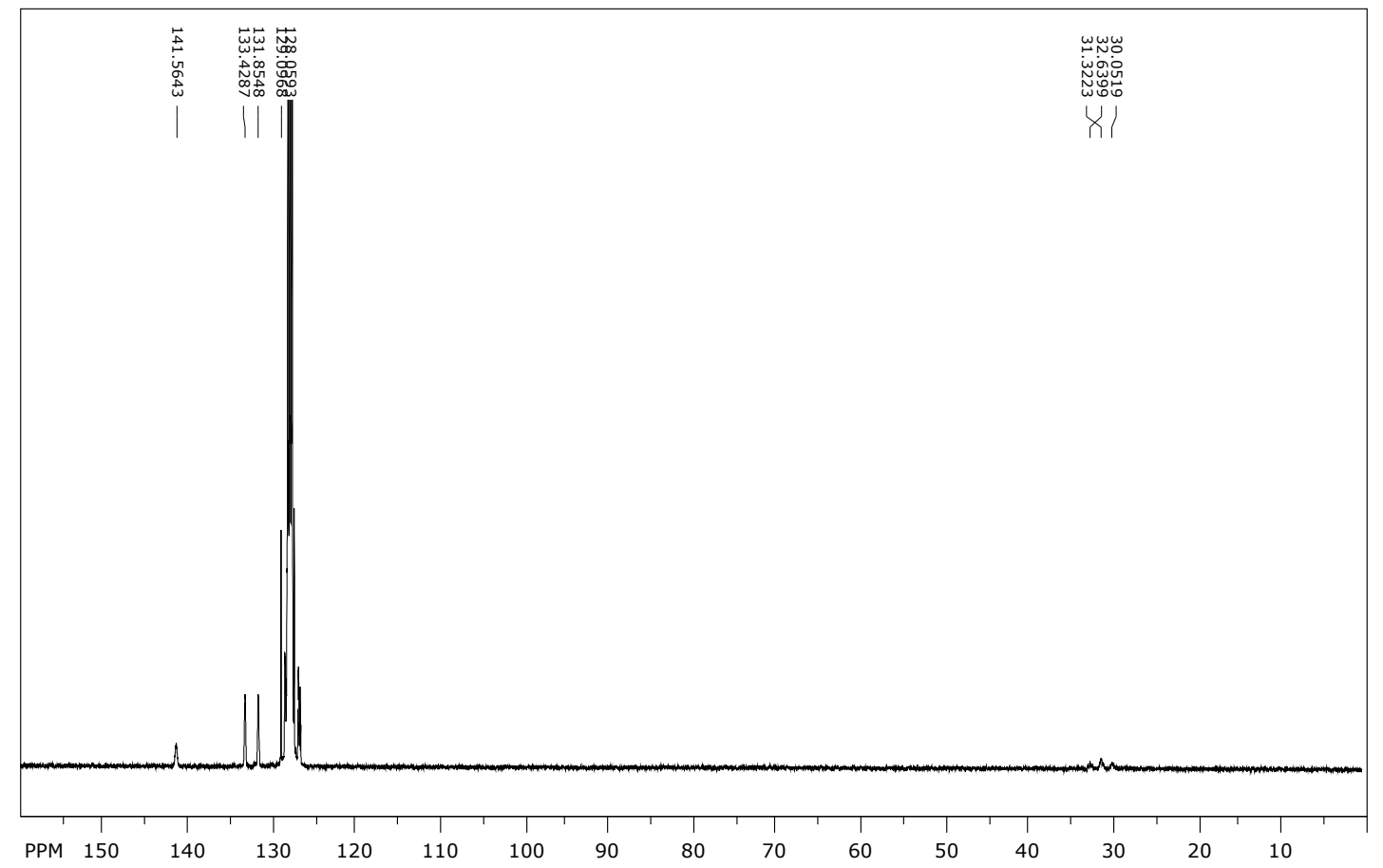

Figure S7. ${ }^{13} \mathrm{C}$ NMR spectrum $\left(100 \mathrm{MHz}\right.$, benzene-d 6 ) of $\mathrm{Ni}\left(\mathrm{dppe}_{2}(\right.$ 5a) after isolation 


\section{S-2-3. Reaction of 1 with dppp}

The reaction was similarly conducted to that with dppe. The yield of $\mathbf{5 b}$ was $32 \%$ upon crystallization. ${ }^{1} \mathrm{H}$ NMR (400 MHz, $\left.\mathrm{C}_{6} \mathrm{D}_{6}\right): \delta=2.23(\mathrm{br}, 4 \mathrm{H}), 3.58(\mathrm{br}, 2 \mathrm{H}), 6.97(\mathrm{~m}, 12 \mathrm{H}), 7.50(\mathrm{br}, 8 \mathrm{H}) .{ }^{13} \mathrm{C}$ NMR $\left(100 \mathrm{MHz}, \mathrm{C}_{6} \mathrm{D}_{6}\right): \delta=18.10,19.39,20.71,30.32,31.51,32.71,126.86,132.23,133.80,142.39 .{ }^{31} \mathrm{P}$ $\operatorname{NMR}\left(162 \mathrm{MHz}, \mathrm{C}_{6} \mathrm{D}_{6}\right): \delta=13.4(\mathrm{~s})$.

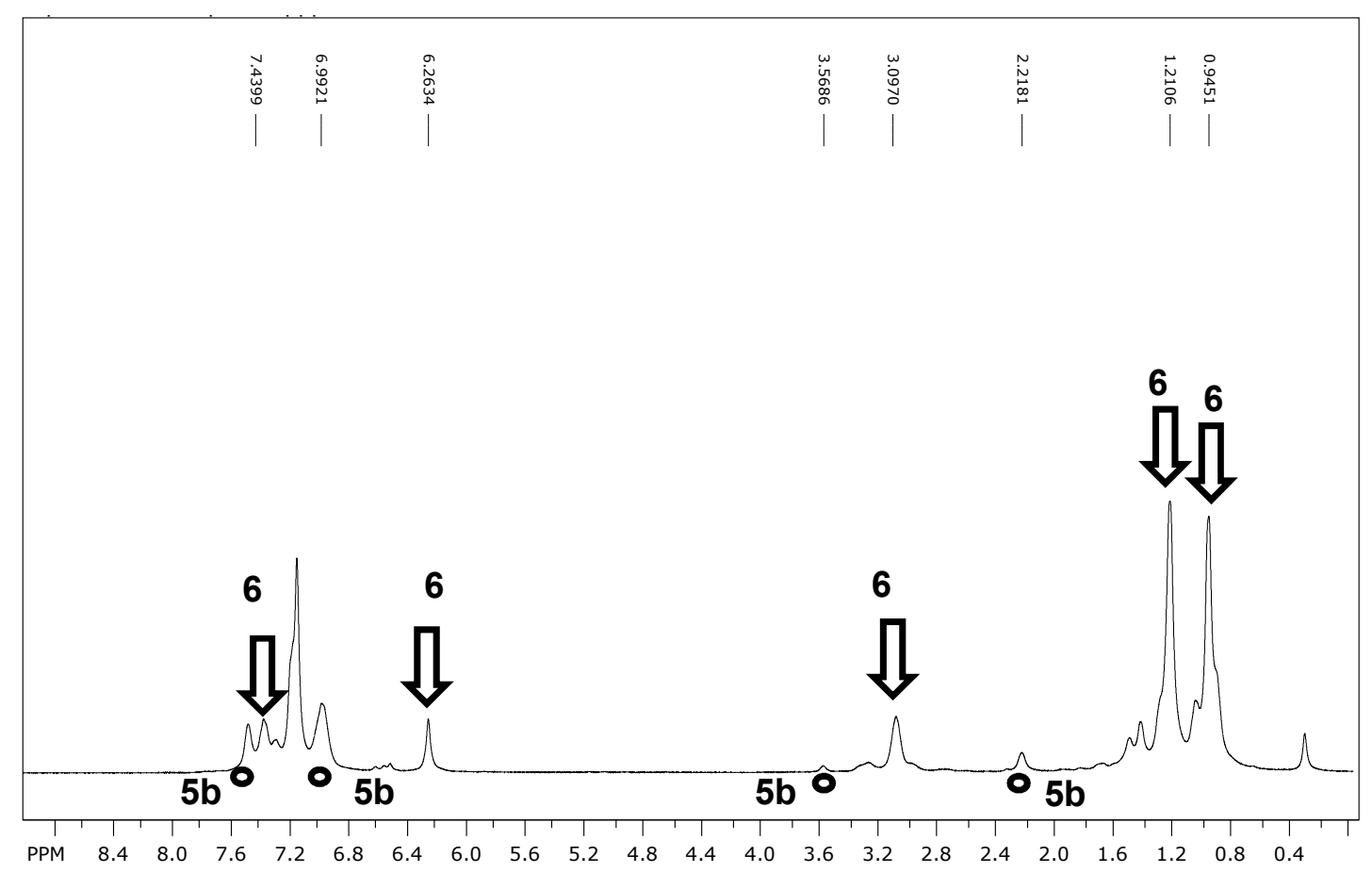

Figure S8. ${ }^{1} \mathrm{H}$ NMR spectrum ( $400 \mathrm{MHz}$, benzene- $\mathrm{d}_{6}$ ) of the reaction mixture containing $\mathbf{5 b}(\mathrm{O})$ and $\mathbf{6}$ $(\downarrow)$. 


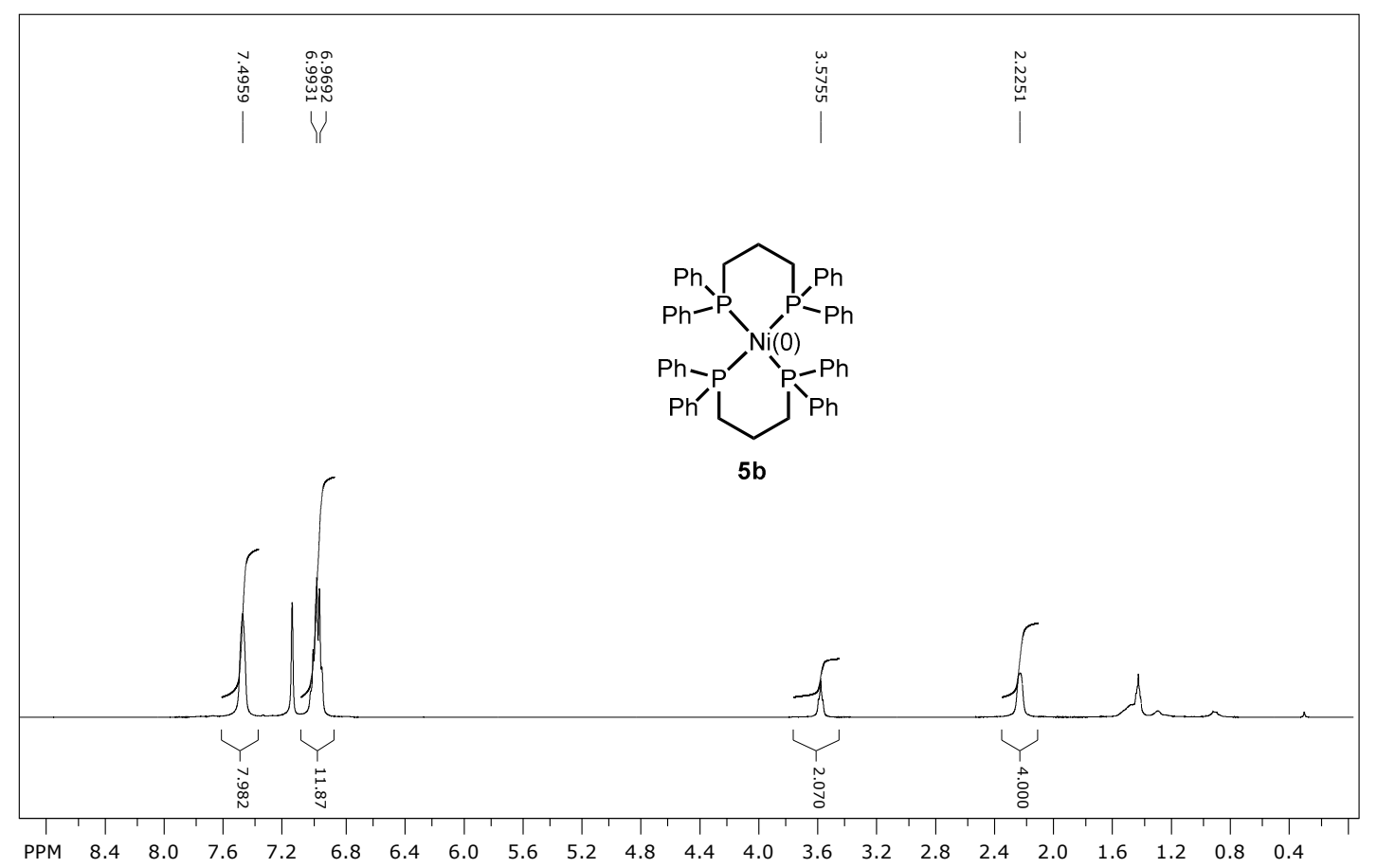

Figure S9. ${ }^{1} \mathrm{H}$ NMR spectrum $\left(400 \mathrm{MHz}\right.$, benzene- $\left.\mathrm{d}_{6}\right)$ of $\mathrm{Ni}(\mathrm{dppp})_{2}(\mathbf{5 b})$ after isolation

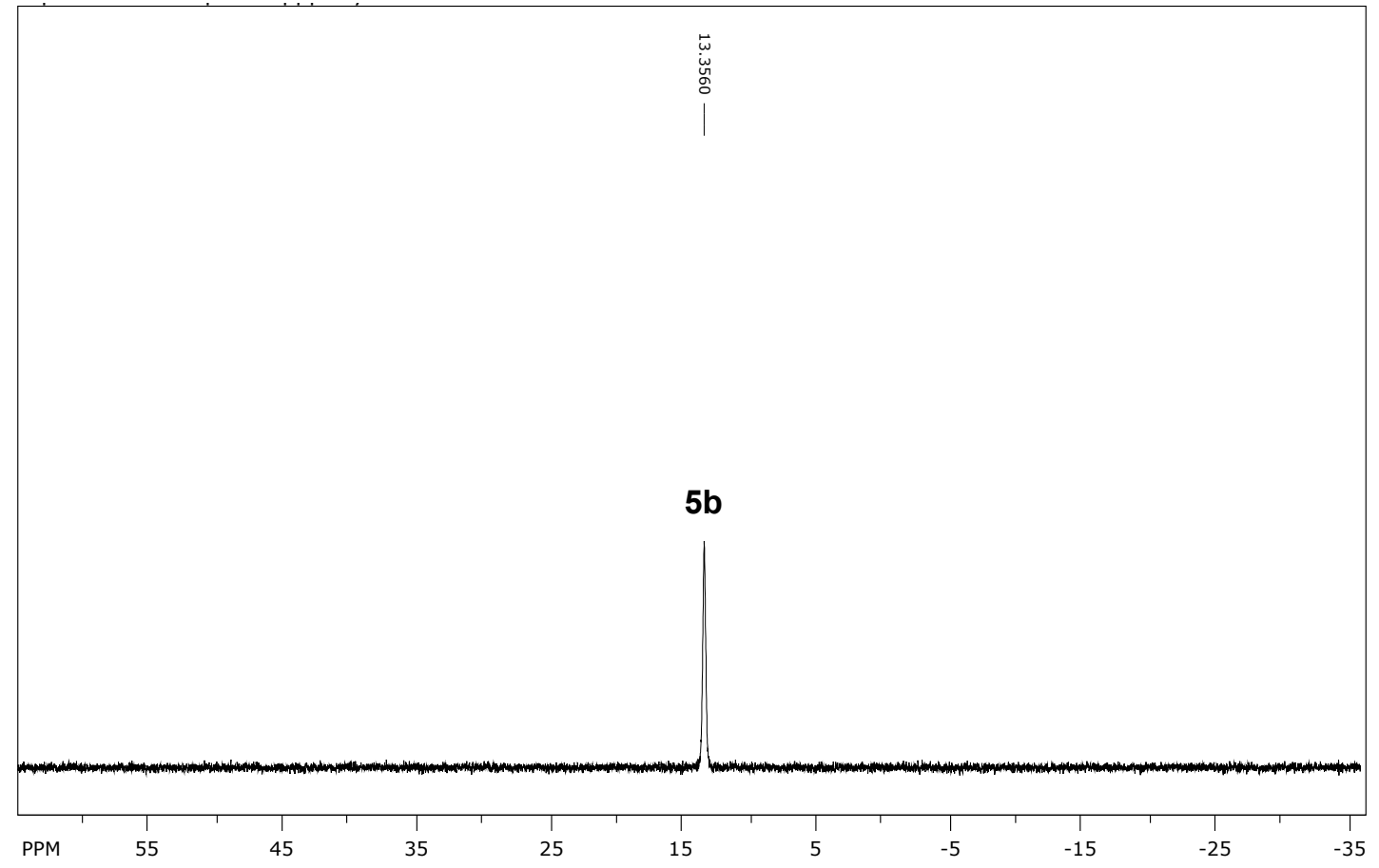

Figure S10. ${ }^{31} \mathrm{P}$ NMR spectrum $\left(162 \mathrm{MHz}\right.$, benzene-d $\left.\mathrm{d}_{6}\right)$ of $\mathrm{Ni}(\mathrm{dppp})_{2}(\mathbf{5 b})$ after isolation 


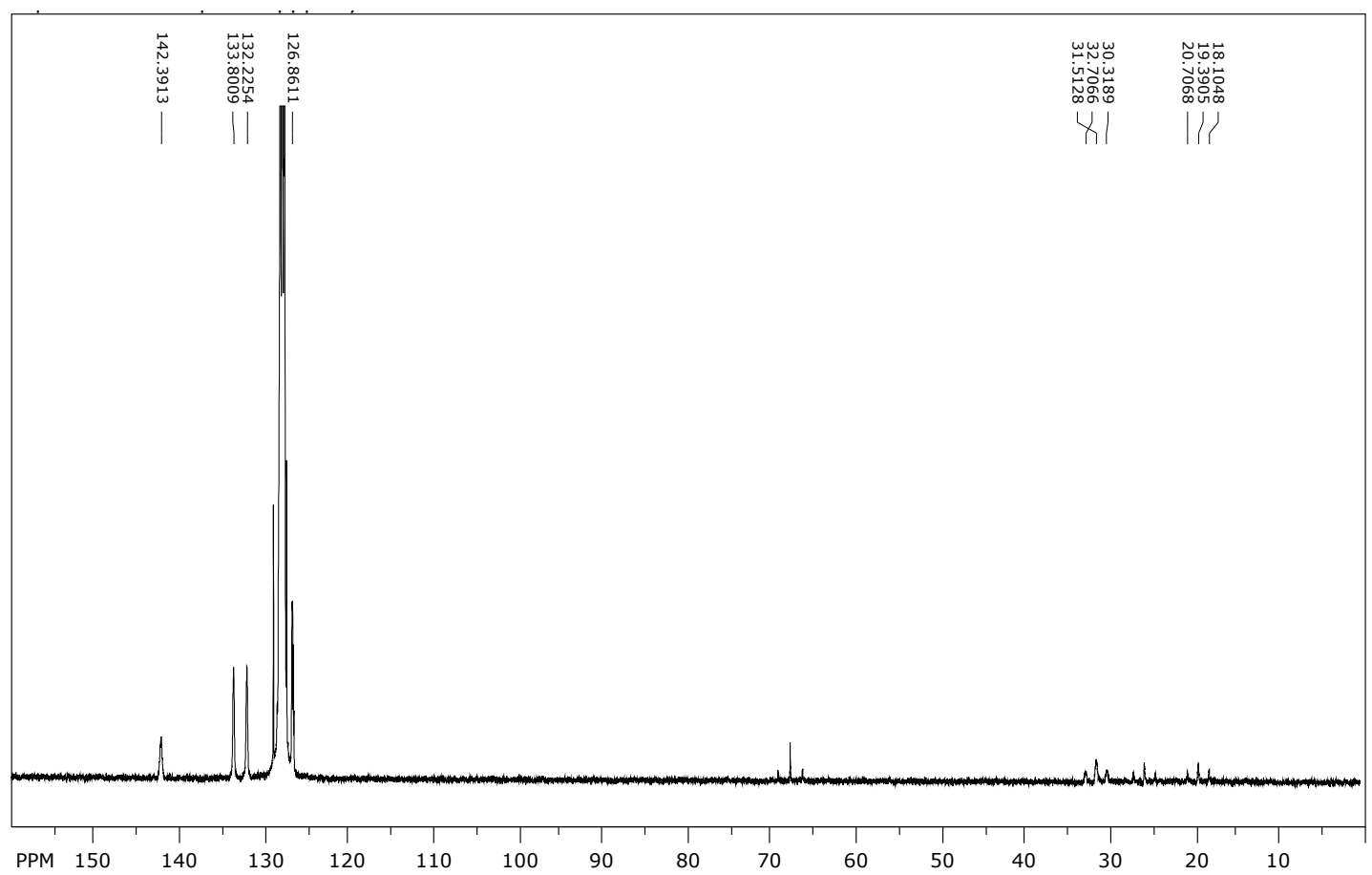

Figure S11. ${ }^{13} \mathrm{C}$ NMR spectrum $\left(100 \mathrm{MHz}\right.$, benzene- $\left.\mathrm{d}_{6}\right)$ of $\mathrm{Ni}(\mathrm{dppp})_{2}(\mathbf{5 b})$ after isolation

\section{S-2-4. Monitoring of the Disproportionation of $2 \mathrm{~d}$ in Benzene-d 6}

The isolated crystals of $\mathbf{2 d}$ was dissolved in benzene- $\mathrm{d}_{6}$ and added to an NMR tube. The ${ }^{1} \mathrm{H}$ and ${ }^{31} \mathrm{P}$ NMR spectra were recorded, and monitored the sample using the NMR spectroscopy. After $18 \mathrm{~h}$, formation of $\mathbf{5 c}$ was confirmed in the ${ }^{31} \mathrm{P}$ NMR spectra (Figure S12), showing appearance of the signal at $\delta 26.97$, which was consistent with that in the literature. ${ }^{2}$ Additionally, the characteristic broad signals from 2d have disappeared and concomitant generation of 6 was detected by the ${ }^{1} \mathrm{H}$ NMR spectra (Figure S13). Some decomposition reactions proceeded concomitantly in the absence of excess amount of DPPB, showing several undefined signals in the ${ }^{31} \mathrm{P}$ and ${ }^{1} \mathrm{H}$ NMR spectra. 


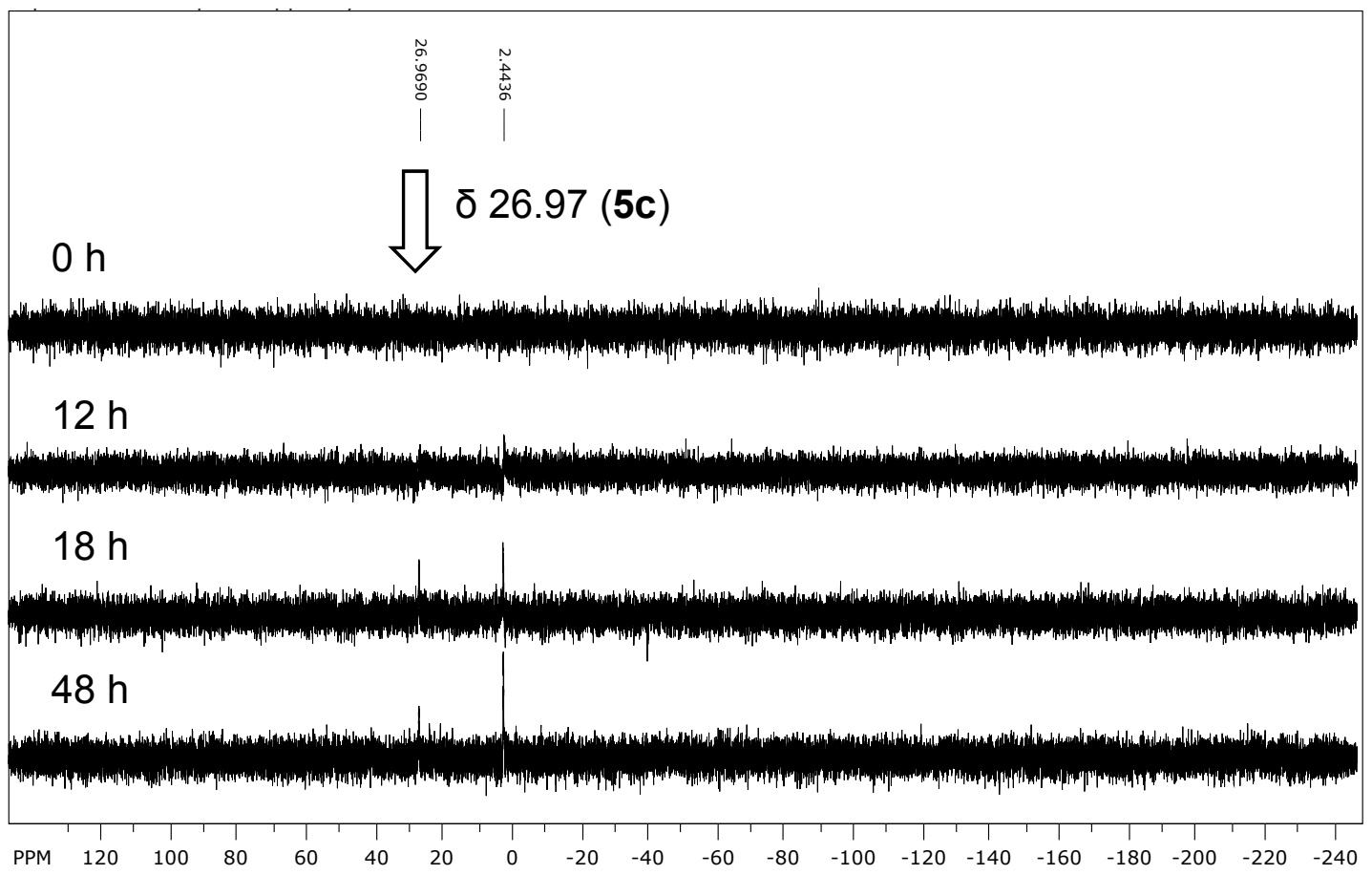

Figure S12. Monitoring of the ${ }^{31} \mathrm{P}$ NMR spectroscopy $\left(162 \mathrm{MHz}\right.$, benzene- $\left.\mathrm{d}_{6}\right)$ of $[\mathrm{NiCl}(\mathrm{IPr})]_{2}(\mathrm{dppb})$ (2d) to generate $\mathbf{5 c}(\delta 26.97)$ at room temperature for $48 \mathrm{~h}$.

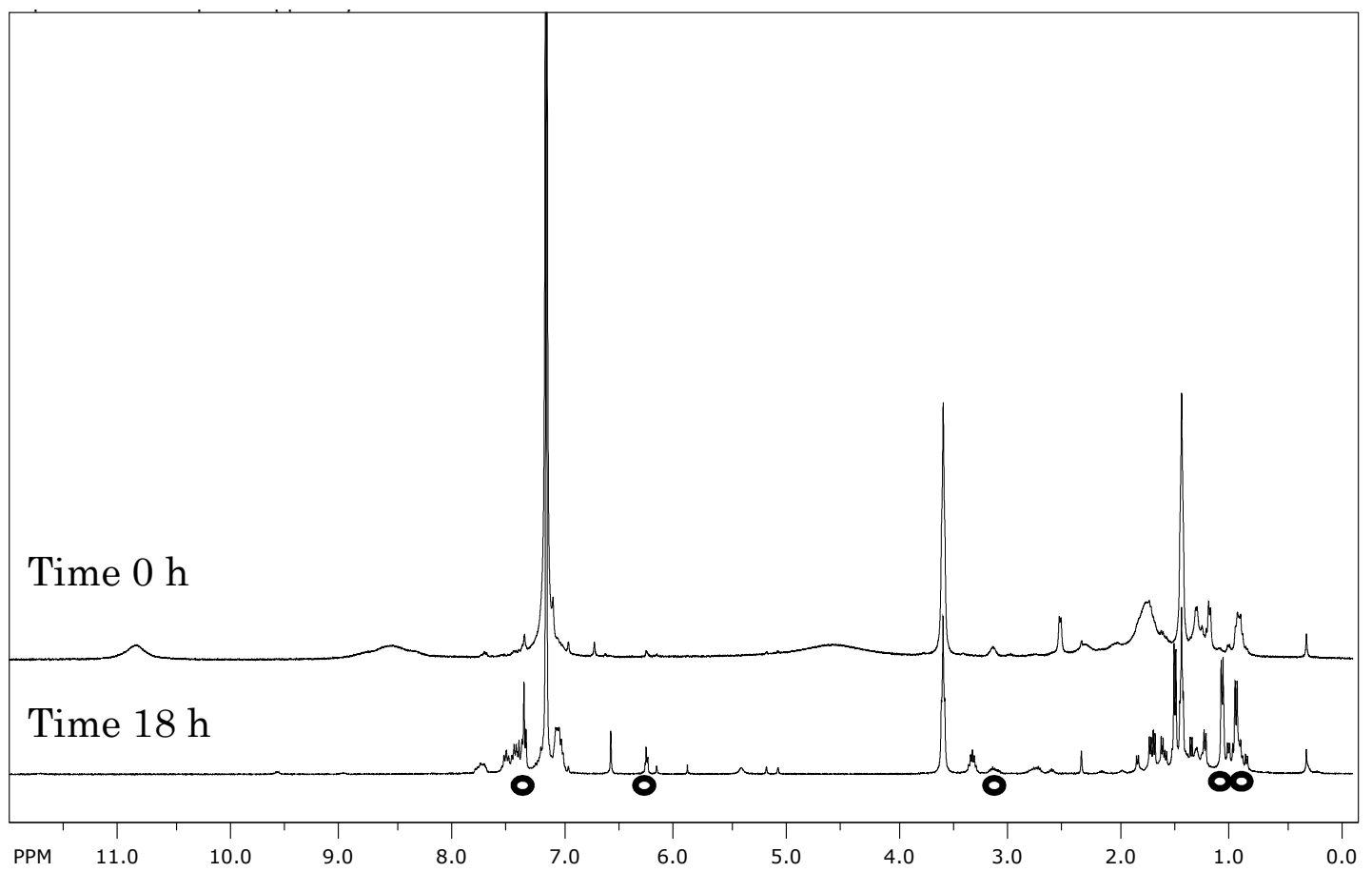

Figure S13. ${ }^{1} \mathrm{H}$ NMR spectra $\left(400 \mathrm{MHz}\right.$, benzene- $\left.\mathrm{d}_{6}\right)$ of the starting compound $[\mathrm{NiCl}(\mathrm{IPr})]_{2}(\mathrm{dppb})(\mathbf{2 d})$ and that after $18 \mathrm{~h}$ to generate $\mathbf{6}(\mathrm{O})$ 


\section{S-3. Preparation of the Monomeric IMes Complexes}

[NiCl(PPh $\mathbf{3})(\mathbf{I M e s})]$ (3a) : The $\mathrm{Ni}(\mathrm{I})$ complex was prepared according to the similar method with

literature. ${ }^{3}$ A solution of 1,3-bis(2,4,6-trimethylphenyl)imidazolium chloride, IMes/ $\mathrm{HCl}$ (428 mg, 1.26 mmol) with $\mathrm{KN}\left(\mathrm{SiMe}_{3}\right)_{2}(253 \mathrm{mg}, 1.26 \mathrm{mmol})$ in $\mathrm{THF}(20 \mathrm{~mL})$ for $3 \mathrm{~h}$ was added to a mixture of $\mathrm{Ni}$ $(\operatorname{cod})_{2}(158 \mathrm{mg}, 0.57 \mathrm{mmol})$ and $\mathrm{Ni}\left(\mathrm{PPh}_{3}\right) \mathrm{Cl}_{2}(374 \mathrm{mg}, 0.57 \mathrm{mmol})$. The mixture was stirred at room temperature for overnight to afford a dark yellow solution. The yellow solution was filtered through Celite and the solvent removed under vacuum. The yellow solids were then recrystallized from toluene/hexane. Yield: $634 \mathrm{mg}(84 \%) .{ }^{1} \mathrm{H}$ NMR $\left(\mathrm{C}_{6} \mathrm{D}_{6}\right): \delta 1.44$ (bs), 3.24 (bs), 4.46 (bs), 8.26 (bs), 10.99 (bs). Elemental analysis calcd (\%) for $\mathrm{C}_{39} \mathrm{H}_{39} \mathrm{ClN}_{2} \mathrm{NiP}$ : C 70.88, H 5.95, N 4.24; found C 70.52, $\mathrm{H}$ 5.97, N 4.31 .

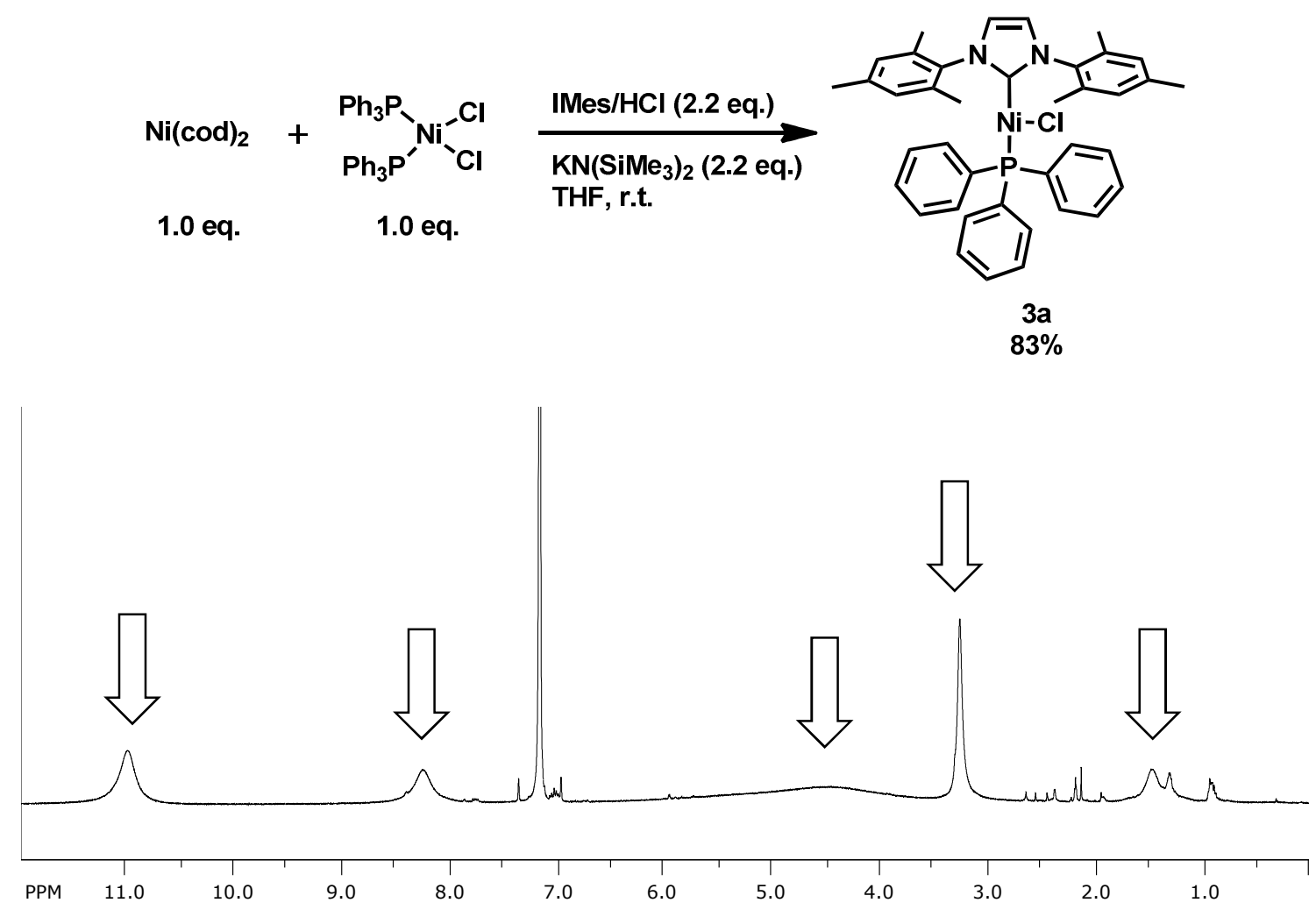

Figure S14. ${ }^{1} \mathrm{H}$ NMR spectra for $3 a\left(400 \mathrm{MHz}\right.$, benzene- $\left.d_{6}\right)$ 
[NiBr(PPh $\left.\mathbf{P P}_{3}(\mathbf{I M e s})\right]$ (3b) : The $\mathrm{Ni}(\mathrm{I})$ complex was prepared according to the similar method with literature. ${ }^{4}$ A solution of 1,3-bis(2,4,6-trimethylphenyl)imidazolium chloride, IMes/HCl (427 mg, 1.26 mmol) with $\mathrm{KN}\left(\mathrm{SiMe}_{3}\right)_{2}(256 \mathrm{mg}, 1.26 \mathrm{mmol})$ in THF $(20 \mathrm{~mL})$ for $4.5 \mathrm{~h}$ was added to a mixture of $\mathrm{Ni}$ $(\operatorname{cod})_{2}(174 \mathrm{mg}, 0.63 \mathrm{mmol})$ and $\mathrm{Ni}\left(\mathrm{PPh}_{3}\right)_{2} \mathrm{Br}_{2}(461 \mathrm{mg}, 0.63 \mathrm{mmol})$. The mixture was stirred at room temperature for overnight to afford a dark yellow solution. The yellow solution was filtered through Celite and the solvent removed under vacuum. The yellow solids were then recrystallized from THF/hexane. Yield: $440 \mathrm{mg}(49 \%) .{ }^{1} \mathrm{H}$ NMR $\left(\mathrm{C}_{6} \mathrm{D}_{6}\right): \delta 1.51$ (bs), 3.20 (bs), 4.35 (bs), 8.23 (d, $J=8.6 \mathrm{~Hz}$, $4 \mathrm{H}), 10.94(\mathrm{~d}, J=8.3 \mathrm{~Hz}, 4 \mathrm{H})$. Elemental analysis calcd (\%) for $\mathrm{C}_{47} \mathrm{H}_{56} \mathrm{BrN}_{2} \mathrm{NiO}_{2} \mathrm{P}: \mathrm{C}$ 66.37, $\mathrm{H}$ 6.64, N 3.29; found C 66.53, H 6.41, N 3.30.

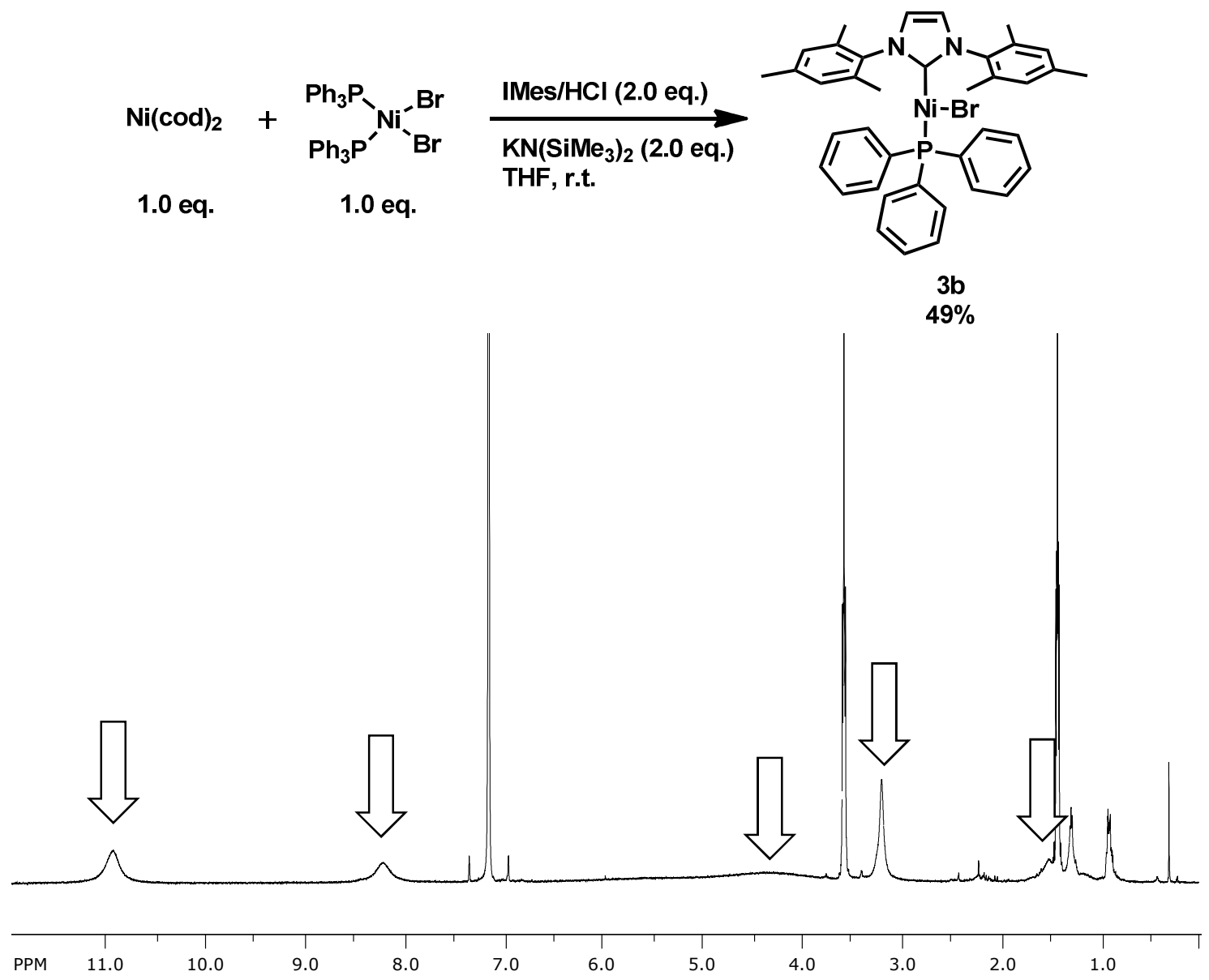

Figure S15. ${ }^{1} \mathrm{H}$ NMR spectra for $\mathbf{3 b}\left(400 \mathrm{MHz}\right.$, benzene- $\left.d_{6}\right)$ 


\section{S-4. Buchwald-Hartwig Amination to Yield Triarylamines}

In a typical example, $1(24.1 \mathrm{mg}, 25 \mu \mathrm{mol})$ and ligand $(300 \mu \mathrm{mol})$, di-p-(tolyl)amine $(118.4 \mathrm{mg}, 0.6$ mmol), $\mathrm{NaO}^{\mathrm{t}} \mathrm{Bu}(71.1 \mathrm{mg}, 0.74 \mathrm{mmol})$, and 4-bromobenzophenone (130.6 mg, $\left.0.5 \mathrm{mmol}\right), \mathrm{THF}$ (0.2 $\mathrm{mL}$ ) were added and stirred at $40^{\circ} \mathrm{C}$ for $24 \mathrm{~h}$. After addition of water, the organic layer was extracted with $\mathrm{CH}_{2} \mathrm{Cl}_{2}$ at three times. The combined organic layer was washed with saturated $\mathrm{NaCl}$ aq. and dried by $\mathrm{Na}_{2} \mathrm{SO}_{4}$, filtered and concentrated in vacuo. The residue was purified by flash column chromatography eluted with ethyl acetate/hexane (1/10) to obtain [4-[bis(4-methylphenyl)amino]phenyl] phenylmethanone as a yellow oil. Each of the yields was $\mathrm{PPh}_{3}(186.9 \mathrm{mg}, 99 \%)$, Pyridine (184.9 mg, 98\%), $\mathrm{P}(\mathrm{OPh})_{3}(73.6 \mathrm{mg}, 39 \%)$.

Product details:

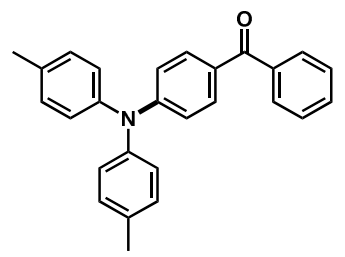

4-(Di-p-tolylamino)benzophenone: (CAS No. 245442-58-4) ${ }^{1} \mathrm{H}$ NMR $\left(\mathrm{CDCl}_{3}\right): \delta 2.34$ (s, 6H), $6.95(\mathrm{~d}, J$ $=8.9 \mathrm{~Hz}, 2 \mathrm{H}), 7.08(\mathrm{~d}, J=8.6 \mathrm{~Hz}, 4 \mathrm{H}), 7.14(\mathrm{~d}, J=8.3 \mathrm{~Hz}, 4 \mathrm{H}), 7.46(\mathrm{t}, J=7.3 \mathrm{~Hz}, 2 \mathrm{H}), 7.55(\mathrm{t}, J=$ $7.4 \mathrm{~Hz}, 1 \mathrm{H}), 7.68$ (d, $J=8.9 \mathrm{~Hz}, 2 \mathrm{H}), 7.76(\mathrm{~d}, J=7.4 \mathrm{~Hz}, 2 \mathrm{H})$. 


\section{S-5. SQUID Measurement of the Ni(I) Complexes}
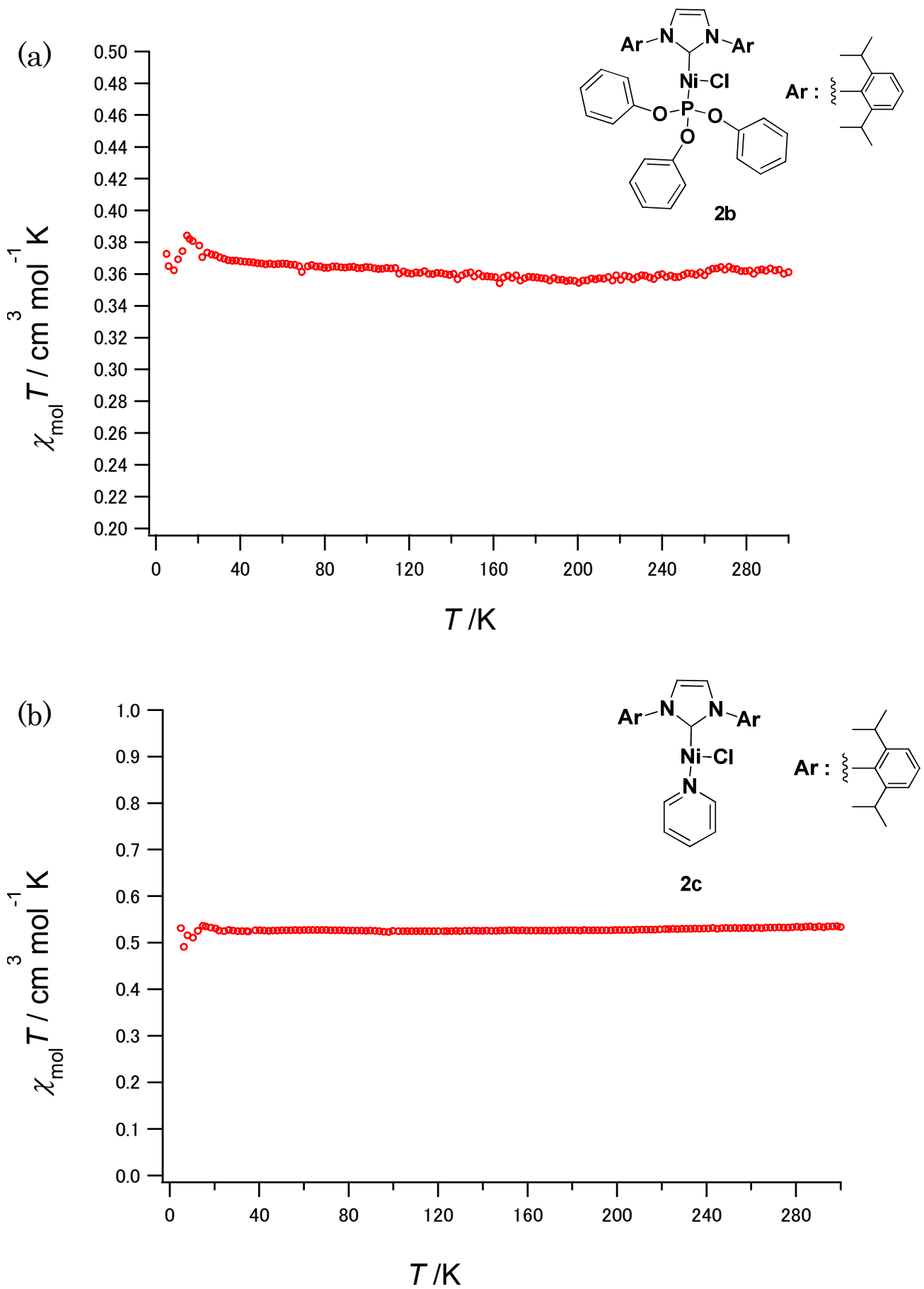


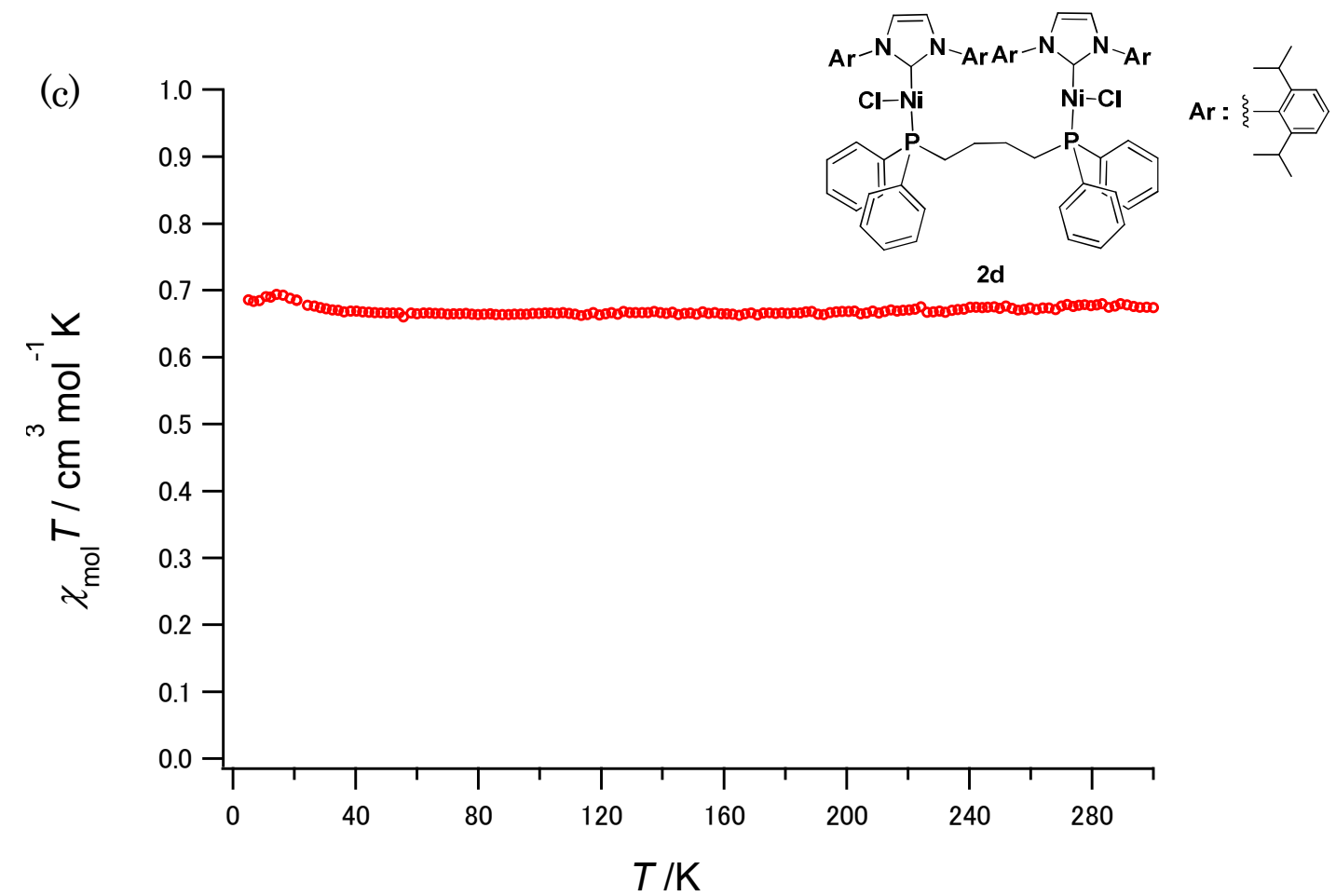

Figure S16. Temperature versus $\chi_{\text {mol }} \mathrm{T}$ plots of complexes (a) $\mathbf{2 b}$, (b) $\mathbf{2 c}$ and (c) $\mathbf{2 d}$ recorded by means of SQUID. 


\section{S-6. Suzuki-Miyaura Cross-Coupling Reaction of Aryl Bromide with Phenylboronic Acid}

In a typical example, aryl bromides $(0.15 \mathrm{mmol})$, phenylboronic acid (20 mg, $0.16 \mathrm{mmol}, 1.1$ equiv.), base (0.66 mmol, 4.4 equiv.), and 3a (11 mg, $15 \mu \mathrm{mol}, 10 \mathrm{~mol} \%)$ were dissolved in solvents $(1 \mathrm{~mL})$. After stirring for overnight at $80^{\circ} \mathrm{C}$, water was added to quench the reaction. The organic layer was extracted with ethyl acetate. The combined organic layer was dried by $\mathrm{Na}_{2} \mathrm{SO}_{4}$, filtered and concentrated in vacuo to obtain white solids. Identification of product was NMR spectroscopy and GC-MS analysis. Product details:

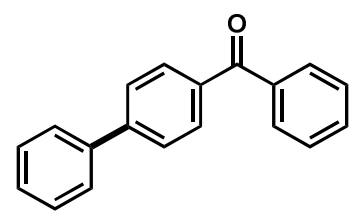

4-Phenylbenzophenone: (CAS \# 2128-93-0) ${ }^{1} \mathrm{H}$ NMR $\left(\mathrm{CDCl}_{3}\right) \delta$ 7.39-7.43(m, 1H), 7.46-7.53 (m, 4H), 7.58-7.63 (m, 1H), 7.64-7.66 (m, 2H), 7.69-7.72 (d, 2H, J = 8.4 Hz), 7.83-7.85 (d, 2H, J = 8.4 Hz), 7.88-7.91 (d,2H, J = 8.4 Hz). GC-MS calcd for $\mathrm{C}_{19} \mathrm{H}_{14}: 258$, found: 258 .

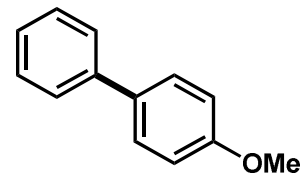

4-Methoxybiphenyl: (CAS \# 613-37-6) GC-MS calcd for $\mathrm{C}_{13} \mathrm{H}_{12}$ : 184, found 184. 


\section{References}

1. Nagao, S.; Matsumoto, T.; Koga, Y. and Matsubara, K. Chem. Lett. 2011, 40, 10361038

2. Fischer, R.; Langer, J.; Malassa, A.; Walther, D.; Görls, H.; Vaughan, G. Chem. Commun. 2006, $2510-2512$.

3. Page, J. M.; Lu, Y. W.; Poulten, C. R.; Carter, E.; Algarra, G. A.; Kariuki, M. B.; Macgregor, A. S.; Mahon, F. M.; Cavell, J. K.; Murphy, M. D. and Whittlesey, K. M. Chem. Eur. J. 2013, 19, 2158 2167. 